\title{
PENGARUH KUALITAS INFORMASI, PERSEPSI RISIKO DAN KEPERCAYAAN TERHADAP KEPUTUSAN PEMBELIAN ONLINE (STUDI PADA KONSUMEN TOKOPEDIA DI KABUPATEN BANTUL)
}

\author{
Fahkrul Eka Saputra ${ }^{1}$ \\ Susanto $^{2}$ \\ Muinah Fadhilah ${ }^{3}$ \\ Fakultas Ekonomi dan Universitas Sarjanawiyata Tamansiswa, Yogyakarta, Indonesia \\ Email : sfahrul41@gmail.com
}

\begin{abstract}
This study aims to determine: (1) the effect of information quality, risk perception, and trust on purchasing decisions on Tokopedia consumers in Bantul Regency (2) the effect of information quality on purchasing decisions on Tokopedia consumers in Bantul Regency (3) the effect of risk perceptions on decisions purchases at Tokopedia consumers in Bantul Regency (4) the effect of trust on purchasing decisions on Tokopedia consumers in Bantul Regency. This research is a quantitative research. The population in this study are consumers who have purchased products or goods for at least the last six months on Tokopedia. The sampling technique used purposive sampling with a total of 100 respondents. The data collection technique uses a questionnaire that has been tested for validity and reliability. The data analysis technique used is multiple regression. The results showed that: (1) there was a positive and significant influence on the quality of information on purchasing decisions at Tokopedia, as evidenced by the $t$-count value of 3.138; the significance value is $0.002<0.05$; and a regression coefficient of 0.214; (2) there is a positive and significant impact on risk perceptions on purchasing decisions on Tokopedia, as evidenced by the $t$ value of 4,750; the significance value is $0.000<0.05$; and a regression coefficient of 0.479; (3) there is a positive and significant effect of trust on purchasing decisions on Tokopedia, as evidenced by the $t$ value of 2.227; the significance value is $0.028<0.05$; and a regression coefficient of 0.128 ; (5) there is a positive influence on information quality, risk perception, and trust in purchasing decisions on Tokopedia, as evidenced by the calculated $F$ value of 20.096 with a significance of $0.00<0.05$.
\end{abstract}

Keywords: $\quad$ Information Quality, Risk Perception, Trust, Purchase Decision, Online Shop

\section{PENDAHULUAN}

Perkembangan teknologi yang pesat di masa sekarang yang ditandai dengan munculnya berbagai inovasi terbaru dan disertai oleh meratanya fasilitas internet di Indonesia membuat peluang tersendiri bagi pelaku bisnis untuk meraup keuntungan melalui E-commerce.Berkembangnya E-Commerce tidak lepas dari perilaku konsumen dalam melakukan pembelian online.Bisnis online atau e-commerce sekarang telah menjamur. Hal ini tidak terlepas dari berbagai kemudahan berbelanja online yang tidak didapat langsung ketika belanja secara offline.

Bisnis online merupakan segala kegiatan (bisnis/urusan/kepentingan/kebutuhan) yang menggunakan fasilitas internet sebagai sarana mencapai tujuan (keuntungan/profit).Berkembangnya $e$ commerce di Indonesia telah menggeser minat masyarakat yang dulunya belanja secara langsung dengan mendatangi tokonya menjadi belanja secara online. Selama konsumen memiliki perangkat yang 


\section{Journal Competency of Business 2018 Vol 2. No I}

tersambung ke internet, maka konsumen tidak perlu mendatangi tokonya untuk berbelanja barang atau menggunakan jasa.

Banyaknya toko online yang ada di Indonesia membuat pilihan konsumen semakin beragam, konsumen tidak perlu mendatangi tokonya secara langsung, karena mereka dapat memilih produk atau barang yang akan mereka beli dari rumah selama ada internet dan gadget.Menjamurnya toko online di Indonesia menandakan bahwa Indonesia merupakan pasar yang menjanjikan bagi bisnis ini. Hal ini dikarenakan minat masyarakat yang dulunya berbelanja secara offline bergeser menjadi belanja secara online. Hal ini didukung dengan catatan data survei yang dilakukan oleh Asosiasi Penyelenggara Jasa Internet Indonesia (APJII) pada tahun 2018yang menunjukan pertumbuhan pengguna internet di Indonesia selama 2017-2018 sebanyak $10,12 \%$ atau berjumlah 27.916.716.

Meningkatnya pertumbuhan teknologi serta bertambahnya pengguna internet di Indonesia membuat peluang e-commerce terbuka lebar. Hal ini yang mendasari Tokopedia untuk ikut serta dalam meramaikan e-commerce yang ada di Indonesia. Tokopedia diperkenalkan pada publik pada tanggal 17 agustus 2009 dibawah naungan PT. Tokopedia yang di dirikan oleh William Tanuwijaya dan Leontinus Alpha Edison. Sejak resmi diluncurkan, PT. Tokopedia yang mempunyai slogan Mulai Aja Dulu berhasil menjadi salah satu perusahaan internet Indonesia dengan pertumbuhan yang sangat pesat. Pada kuartal 2 (Q2) 2019 sendiri situs web Tokopedia menurut iPrice dikunjungi sebanyak 140,414,500.

Risiko dari belanja online menggunakan aplikasi Tokopedia antara lain banyaknya pemasar yang memasarkan produknya di aplikasi Tokopedia, sehingga membuat konsumen kesulitan menentukan pemasar yang kredibel yang pembeli bisa percayai. Selain itu, terdapat perbedaan harapan antara barang yang datang dengan barang yang dilihat pada katalog pemasar di aplikasi Tokopedia. Kekurangan inilah yang kemudian menjadi berbagai risiko yang harus dipertimbangkan konsumen dalam menentukan pembelian melalui aplikasi Tokopedia. Xian et al. (2012) mengatakan pada belanja online, risiko muncul dikarenakan tidak adanya interaksi langsung antara pemasar dan konsumen, sehingga konsumen cenderung berspekulasi terhadap kredibilitas pemasar ataupun kualitas barang yang dipasarkan.

Berdasarkan fenomena yang telah diuraikan di atas, peneliti tertarik untuk melakukan penelitian tentang Pengaruh Kepercayaan, Kualitas Informasi, dan Persepsi Risiko terhadap Keputusan Pembelian.

\section{Keputusan Pembelian}

Kotler dan Armstrong (2016:177) mendefinisikan keputusan pembelian sebagai bagian dari perilaku konsumen yaitu studi tentang bagaimana individu, kelompok, dan organisasi memilih, menggunakan, membeli, dan bagaimana barang, jasa, ide atau pengalaman untuk memuaskan kebutuhan dan keinginan konsumen.Dari berbagai faktor yang mempengaruhi konsumen dalam melakukan pembelian suatu produk atau jasa, biasanya konsumen selalu mempertimbangkan kualitas, harga dan produk yang sudah dikenal oleh masyarakat. Sedangkan menurut Machfoedz (2013:44) bahwa keputusan pembelian adalah salah satu proses penilaian dan pemilihan dari berbagai alternatif sesuai dengan kepentingan-kepentingan tertentu dengan menetapkan suatu pilihan yang dianggap paling menguntungkan. Belanja online kegiatan belanja yang melalui media internet untuk melakukannya. Melalui belanja lewat internet seorang pembeli tidak perlu datang ke tokonya secara langsung, karena barang atau produk dapat dilihat di situs web penjual selama ada media internet dan gadget.

Umumnya setiap konsumen melakukan keputusan mengenai pencarian, pembelian, penggunaan suatu produk dan merek pada setiap waktu. Konsumen melakukan keputusan pembelian hampir harinya atau setiap waktu tanpa disadari bahwa konsumen telah mengambil keputusan. Pengambilan keputusan oleh konsumen berbeda-beda tergantung oleh jenis keputusan belinya. Kepercayaan dan Kualitas Informasi secara simultan berpengaruh positif terhadap keputusan pembelian(Pudjihardjo dan Helen Wijaya, 2015), Persepsi risiko dan kepercayaan berpengaruh positif terhadap keputusan pembelian (Isnain 


\section{Journal Competency of Business 2018 Vol 2. No I}

dan Guruh, 2014). Berdasarkan penjelasan dan hasil penelitian yang sudah dijelaskan di atas, maka hipotesis pertama yang diajukan adalah :

\section{H1 : Kualitas Informasi, Persepsi Risiko, dan Kepercayaan berpengaruh positif terhadap} Keputusan Pembelian

\section{Kualitas Informasi}

Kualitas informasi didefinisikan sebagai persepsi pelanggan terhadap kualitas informasi tentang produk atau layanan yang disediakan oleh sebuah website (Park dan Kim, 2003, dalam Loo, 2011). Informasi atribut dari suatu produk adalah informasi tentang spesifikasi produk, yaitu dimensi warna, ukuran, teknologi, bahan, dan harga dasar suatu produk. Informasi yang disajikan pada online shop sebaiknya mencakup informasi berkaitan dengan produk dan jasa yang ada pada online shopping.Menurut Sutabri (2012:33), kualitas dari suatu informasi tergantung pada 3 hal, yaitu informasi harus akurat, tepat waktu, dan relevan.

a. Akurat, yaitu informasi harus bebas dari kesalahan dan mencerminkan keadaan yang sebenarnya

b. Tepat waktu, yaitu informasi yang datang pada penerima tidak boleh terlambat karena untuk mengambil suatu keputusan dibutuhkan informasi yang tepat waktu.

c. Relevan, yaitu informasi harus bermanfaat bagi pemakainya

Dari penelitian terdahulu bahwa kualitas informasi berpengaruh positif terhadap keputusan pembelian (Rizki et al., 2015), maka berdasarkan penjelasan dan penelitian sebelumnya yang sudah dijelaskan, hipotesis kedua yang diajukan adalah :

\section{H2: Kualitas Informasi berpengaruh positif terhadap Keputusan Pembelian}

\section{Persepsi Risiko}

Peneliti-peneliti perilaku konsumen mendefinisikan persepsi risiko sebagai persepsi konsumen tentang ketidakpastian dan akibat yang merugikan karena pembelian suatu produk atau jasa. Persepsi risiko meningkat melalui ketidakpastian atau besarnya hubungan konsekuensi yang negatif. Risiko pada online shopping sebagai keinginan tertentu subjektif dari kerugian pembelian yang dianggap dalam beberapa pembelian online, Forsythe dan Shi dalam Juniawati (2014).

Menurut Sukma (2011) risiko dari suatu produk mengacu pada ketidakpastian bahwa produk yang akan dibeli sesuai dengan harapan atau tidak, sedangkan risiko transaksi adalah ketidakpastian yang berakibat pada kerugian konsumen selama proses transaksi, dan risiko psikologis adalah ketakutanketakutan yang terjadi sebelum maupun setelah pembelian. Ketika persepsi risiko menjadi tinggi, konsumen akan mempertimbangkan apakah akan menghindari pembelian untuk meminimalisir kerugian, atau meminimalisir risiko melalui pencarian dan alternaltif evalusai sebelum pembelian dalam tahap pengambilan keputusan pembelian. Kondisi ini menghasilkan pengambilan keputusan yang kompleks. Konsumen mungkin akan mengevaluasi suatu produk dari merek tertentu secara detail. Informasi mengenai produk sangat dibutuhkan guna menghindari risiko yang merugikan dan konsumen mencoba mengevaluasi berbagai merek. Proses pengambilan keputusan yang demikian menggambarkan adanya keterlibatan konsumen dengan suatu produk.

Penelitian sebelumnya menjelaskan bahwa Persepsi Risiko berpengaruh positif terhadap Keputusan Pembelian (Muhammad Ashur, 2016). Berdasarkan penjelasan dan penelitian sebelumnya, maka hipotesis ketiga yang diajukan adalah :

\section{H3: Persepsi Risiko berpengaruh positif terhadap keputusan pembelian}

\section{Kepercayaan}

Menurut pendapat Kotler dan Keller (2012: 125) kepercayaan merupakan komponen kognitif dari faktor psikologis. Kepercayaan berhubungan dengan keyakinan, bahwa sesuatu itu benar atau salah atas 


\section{Journal Competency of Business 2018 Vol 2. No I}

dasar bukti, sugesti, otoritas, pengalaman dan intuisi. Menurut Li et al. (2014) menyatakan kepercayaan lebih penting saat kita belanja online daripada belanja offline, konsumen lebih banyak mempersepsikan risiko dalam e-commercekarena ketidakmampuan konsumen untuk mengunjungi toko secara langsung dan memeriksa barang yang konsumen minati. Kepercayaan akan ada ketika konsumen puas dengan produk atau barang yang telah mereka gunakan dengan merek tertentu. Konsumen yang telah merasakan kepuasan dan nyaman akan suatu produk, akan terus memilih produk tersebut untuk kebutuhannya dan tidak akan meninggalkan atau memilih produk merek lain. Oleh sebab itu merek identitas merek sangat penting bagi suatu produk. Suatu merek harus dapat memberikan keyakinan atau kepercayaan kepada konsumen bahwa merek tersebut dapat dipercaya. Dengan dibangunnya sebuah kepercayaan oleh sebuah perusahaan, maka calon konsumen akan yakin bahwa produk-produk yang dikeluarkan oleh perusahaan tersebut akan mampu memenuhi kebutuhan dan keinginan konsumen.

Ketika terjadi penipuan dan pengalaman belanja online yang buruk, maka konsumen akan menghasilkan sikap yang negatif, sehingga konsumen

tidak akan lagi mempercayai penjual dan konsumen cenderung akan mencari jalan alternatif untuk memenuhi kebutuhan dan keinginan konsumen itu sendiri (Lee, 2014). Sikap negatif konsumen yang dimaksud adalah konsumen tidak akan mempercayai lagi toko online tersebut, memberi rating yang buruk serta memberikan komentar pada kolom review dengan jelek. Hal ini tentu sangat merugikan toko online tersebut, mengingat rating dan review dari konsumen merupakan hal yang vital dan sangat penting bagi berlangsungnya penjualan online.

Kepercayaan memiliki pengaruh positif terhadap keputusan pembelian di online shop (Istiqomah dan Hidayat, 2019). Berdasarkan penjelasan diatas dan hasil dari penelitian sebelumnya, maka hipotesis terakhir yang diajukan adalah :

\section{H4 : Kepercayaan berpengaruh positif terhadap keputusan pembelian}

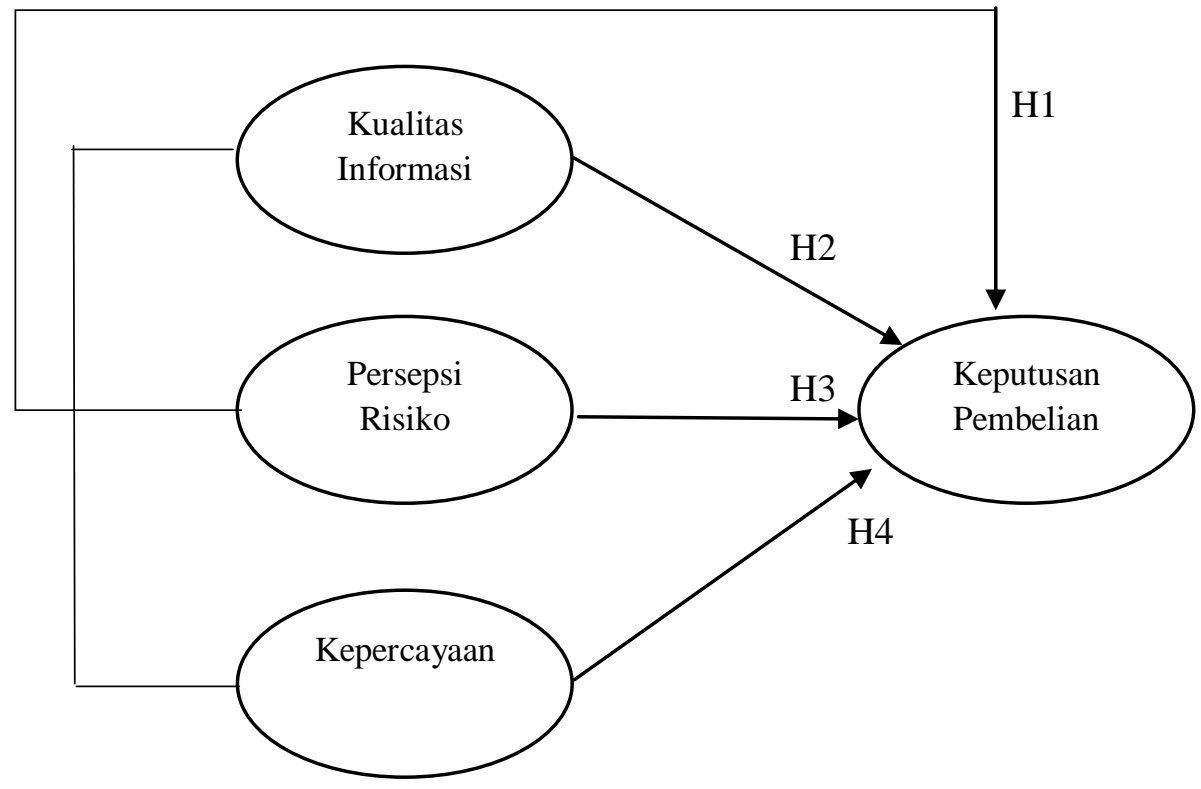




\section{Journal Competency of Business 2018 Vol 2. No I}

\section{MODEL PENELITIAN}

Gambar 1. Model Penelitian

Penelitian ini bersifat kuantitatif dimana penelitian lebih cenderung menggunakan analisis yang berupa data kemudian berakhir dengan penerimaan atau penolakan terhadap teori yang digunakan. Tujuan penelitian kuantitatif yaitu menjelaskan fenomena yang sedang terjadi di dalam masyarakat secara mendalam dengan cara mengumpulkan data yang akan dikembangkan menggunakan model-model matematis, teori-teori, serta hipotesis yang berkaitan dengan fenomena yang sedang terjadi. Penelitian ini dilakukan pada konsumen Tokopedia di Kabupaten Bantul.

Populasi pada penelitian ini adalah konsumen Tokopedia yang pernah membeli produk di wilayah Yogyakarta. Sampel dalam penelitian ini berupakonsumen Tokopedia yang berada di Kabupaten Bantul dengan jumlah 100 orang.Teknik pengambilan data dalam penelitian ini menggunakan kuesioner. Kuesioner digunakan untuk memperoleh data responden mengenai kualitas informasi, persepsi risiko, kepercayaan, dan keputusan pembelian.Teknik pengambilan sampel yang dipakai adalah non probability sampling dengan purposive sampling atau pengambilan sampel berdasarkan karakteristik tertentu, seperti Responden berdomisili di Yogyakarta, Responden pernah melakukan pembelian minimal sekali di Tokopedia, dan Waktu pembelian yang pernah dilakukan responden minimal 6 bulan terakhir.

Dalam penelitian ini menggunakan kuesioner yang disusun secara otomatis beberapa pertanyaan yang diberikan kepada responden yang dinilai dengan skala likert.

\section{TEKNIK ANALISIS DATA}

\section{Uji Validitas}

Uji validitas adalah uji yang dilakukan untuk memastikan kemampuan sebuah skala untuk mengukur konsep yang dimaksudkan. Berikut di bawah ini adalah hasil uji validitas dari keempat variabel:

Tabel 1 Hasil Uji Validitas

\begin{tabular}{|l|l|l|l|l|l|}
\hline \multirow{4}{*}{ Variabel } & item & Sig & Rhitung & Rtabel & keterangan \\
\hline \multirow{4}{*}{$\begin{array}{l}\text { Keputusuan } \\
\text { Pembelian }\end{array}$} & Item 1 & 0,000 & 0,609 & 0.195 & Valid \\
\cline { 2 - 6 } & Item 2 & 0,000 & 0,452 & 0.195 & Valid \\
\cline { 2 - 6 } & Item 3 & 0,000 & 0,584 & 0.195 & Valid \\
\cline { 2 - 6 } & Item 4 & 0,000 & 0,640 & 0.195 & Valid \\
\cline { 2 - 6 } & Item 5 & 0,000 & 0,552 & 0.195 & Valid \\
\hline \multirow{4}{*}{$\begin{array}{l}\text { Kualitas } \\
\text { Informasi }\end{array}$} & Item 1 & 0,000 & 0,742 & 0.195 & Valid \\
\cline { 2 - 6 } & Item 2 & 0,000 & 0,730 & 0.195 & Valid \\
\cline { 2 - 6 } & Item 3 & 0,000 & 0,795 & 0.195 & Valid \\
\cline { 2 - 6 } & Item 4 & 0,000 & 0,817 & 0.195 & Valid \\
\hline \multirow{2}{*}{$\begin{array}{l}\text { Persepsi } \\
\text { Risiko }\end{array}$} & Item 1 & 0,000 & 0,763 & 0.195 & Valid \\
\cline { 2 - 6 } & Item 2 & 0,000 & 0,756 & 0.195 & Valid \\
\hline
\end{tabular}


2018 Vol 2. No I

\begin{tabular}{|l|l|l|l|l|l|}
\hline & Item 3 & 0,000 & 0,800 & 0.195 & Valid \\
\hline \multirow{4}{*}{ Kepercayaan } & Item 1 & 0,000 & 0,693 & 0.195 & Valid \\
\cline { 2 - 6 } & Item 2 & 0,000 & 0,716 & 0.195 & Valid \\
\cline { 2 - 6 } & Item 3 & 0,000 & 0,711 & 0.195 & Valid \\
\cline { 2 - 6 } & Item 4 & 0,000 & 0,685 & 0.195 & Valid \\
\cline { 2 - 6 } & Item 5 & 0,000 & 0,613 & 0.195 & Valid \\
\cline { 2 - 6 } & Item 6 & 0,000 & 0,564 & 0.195 & Valid \\
\hline
\end{tabular}

Berdasarkan tabel di atas menunjukkan besarnya nilai signifikansi seluruh butir pertanyaan nilainya lebih kecil dari 0,05 dan rhitung lebih besar dari rtabel. Dapat disimpulkan bahwa semua indikator variabel dinyatakan valid dan bisa untuk uji selanjutnya, yaitu uji regresi linier berganda.

\section{Uji Reliabilitas}

Uji reliabilitas merupakan alat untuk mengukur suatu kuesioner yang merupakan indikator dari variabel atau konstruk. Uji reliabilitas dilakukan untuk mengetahui konsistensi dan ketepatan pengukuran, apabila pengukuran dilakukan pada objek yang sama berulang kali dengan instrumen yang sama. Pengujian reliabilitas ditunjukkan oleh koefisien Alpha Cronbach dan dapat diolah dengan bantuan SPSS Uji reliabilitas menggunakan koefisien Cronbach's Alpha dengan bantuan SPSS Hasil pengujian dikatakan reliabel jika nilai Alpha Cronbach> 0.6 dan nilai Alpha Cronbach hitung lebih besar dari pada Cronbach's Alpha if item deleted (Ghozali, 2011:98). Berikut di bawah ini merupakan hasil uji reliabilitas dari keempat variabel :

Tabel 2 Hasil uji reliabilitas

\begin{tabular}{|l|c|c|c|}
\hline Variabel & Alpha Cronbach & Nilai Kritis & Keterangan \\
\hline Keputusan Pembelian & 0,625 & 0,6 & Reliabel \\
\hline Kualitas Informasi & 0,767 & 0,6 & Reliabel \\
\hline Persepsi Risiko & 0,658 & 0,6 & Reliabel \\
\hline Kepercayaan & 0,736 & 0,6 & Reliabel \\
\hline
\end{tabular}

Berdasarkan ringkasan hasil uji reliabilitas seperti yang terangkum dalam tabel 2 di atas, dapat diketahui bahwa nilai koefisien Cronbach Alpha seluruh varaibel penelitian lebih besar dari 0,6. Dengan mengacu pada pendapat yang dikemukakan oleh Ghozali (20011:98), maka semua butir pertanyaan dalam variabel penelitian adalah handal.

\section{HASIL}

\section{Analisis Deskriptif}

Analisis deskriptif pada penelitian ini merupakan analisis karakteristik dari responden,Karakteristik responden yang diamati dalam penelitian ini meliputi jenis kelamin, rentan usia, pendidikan terakhir, pekerjaan dan penghasilan. Deskripsi karakteristik responden disajikan sebagai berikut :

Tabel 3 Karakteristik responden berdasarkan jenis kelamin 


\section{Journal Competency of Business}

2018 Vol 2. No I

\begin{tabular}{ccc}
\hline Jenis Kelamin & Frekuensi & Persentasi \\
\hline Laki-Laki & 63 & $63 \%$ \\
Perempuan & 37 & $37 \%$ \\
\hline Jumlah & 100 & $100 \%$ \\
\hline
\end{tabular}

Berdasarkantabel3diketahui bahwa sebanyak 63 (63\%) respondenberjeniskelaminlaki-laki dan sebanyak 37 (37\%) respondenberjeniskelaminperempuan.

Tabel 4 Karakteristik responden berdasarkan usia

\begin{tabular}{rcc}
\hline Usia & Frekuensi & Presentasi \\
\hline 17-22 tahun & 35 & $35 \%$ \\
$22-27$ tahun & 41 & $41 \%$ \\
$28-32$ tahun & 16 & $16 \%$ \\
Lebih dari 32 tahun & 8 & $8 \%$ \\
\hline Jumlah & 100 & $100 \%$ \\
\hline
\end{tabular}

Berdasarkantabel 4 responden dengan rentanusia 17-22 tahunsebanyak 35 (35\%), usia 22-27 tahunsebanyak 41 (41\%), usia 28-32 tahunsebanyak 16 (16\%) dan yang berusialebihdari 32 tahunsebanyak 8 (8\%). Dapat disimpulkan bahwa mayoritasrespondenberusia 22-27 tahun yang sudahbekerja.

Tabel 5 Karakteristik responden berdasarkan pendidikan terakhir

\begin{tabular}{ccc}
\hline Pendidikan Terakhir & Frekuensi & Persentasi \\
\hline SD & 0 & $0 \%$ \\
SMP & 6 & $6 \%$ \\
SMA Sederajat & 73 & $73 \%$ \\
Perguruan Tinggi & 21 & $21 \%$ \\
\hline Jumlah & 100 & $100 \%$
\end{tabular}

Berdasarkan tabel 5 diketahui bahwa tidak ada responden yang pendidikan terakhirnya hanya sampai bangku Sekolah Dasar, untuk SMP sebanyak 6 (6\%), SMA Sederajat sebanyak 73 (73\%), dan Perguruan Tinggi sebanyak $21(21 \%)$.

Tabel 6 Karakteristik responden berdasarkan pekerjaan

\begin{tabular}{ccc}
\hline Pekerjaan & Frekuensi & Persentase \\
\hline PNS & 8 & $8 \%$ \\
Karyawan Swasta & 33 & $33 \%$
\end{tabular}




\section{Journal Competency of Business 2018 Vol 2. No I}

\begin{tabular}{ccc} 
Wiraswasta & 13 & $13 \%$ \\
Pelajar/Mahasiswa & 42 & $42 \%$ \\
Lainnya & 4 & $4 \%$ \\
\hline Jumlah & 100 & $100 \%$ \\
\hline
\end{tabular}

Berdasarkan tabel diketahui bahwa sebanyak $8(8 \%)$ responden bekerja sebagai PNS, Karyawan Swasta sebanyak 33 (33\%), Wiraswasta sebanyak 13 (13\%), Pelajar atau Mahasiswa sebanyak 42 (42\%), dan $4(4 \%)$ orang memiliki pekerjaan di luar kategori tersebut.

Tabel 7 Karakteristik responden berdasarkan pendapatan

\begin{tabular}{ccc}
\hline Pendapatan & Frekuensi & Persentasi \\
\hline < Rp 1.000.000 & 44 & $44 \%$ \\
Rp 1.000.000 - Rp 2.000.000 & 17 & $17 \%$ \\
Rp 2.000.000 - Rp 3.000.000 & 23 & $23 \%$ \\
$>$ Rp.3.000.000 & 16 & $16 \%$ \\
\hline Jumlah & 100 & $100 \%$ \\
\hline
\end{tabular}

Dari tabel responden dengan penghasilan kurang dari Rp 1.000.000 sebanyak 44 responden (44\%), responden dengan penghasilan Rp1.000.000-Rp2.000.000 sebanyak 17 (17\%), responden dengan penghasilan Rp2.000.000-Rp3.000.000 sebanyak 23 orang (23\%), dan responden dengan penghasilan lebih dari Rp3.000.000 sebanyak 16 orang (16\%).

\section{Analisis Regresi Linier Berganda}

Dalam penelitian ini, dalam menganalisis regresi linear berganda penulis menggunakan seri program statistik SPSS. SPSS adalah suatu program software komputer yang digunakan untuk mengolah data baik parametrik maupun nonparametrik, seperti ditunjukkan pada Tabel berikut ini :

Tabel 8 Hasil uji regresi linier berganda

\begin{tabular}{|c|c|c|c|c|c|c|}
\hline \multicolumn{7}{|c|}{ Coefficients $^{a}$} \\
\hline \multirow[b]{2}{*}{ Mod } & & \multicolumn{2}{|c|}{ Unstandardized Coefficients } & \multirow{2}{*}{$\begin{array}{c}\text { Standardized } \\
\text { Coefficients } \\
\text { Beta } \\
\end{array}$} & \multirow[b]{2}{*}{$t$} & \multirow[b]{2}{*}{ Sig. } \\
\hline & & B & Std. Error & & & \\
\hline \multirow[t]{4}{*}{1} & (Constant) & 8.934 & 1.776 & & 5.031 & .000 \\
\hline & KualitasInformasi & .214 & .068 & .255 & 3.138 & .002 \\
\hline & PersepsiRisiko & .479 & .101 & .415 & 4.750 & .000 \\
\hline & Kepercayaan & .128 & .058 & .194 & 2.227 & .028 \\
\hline
\end{tabular}




\section{Journal Competency of Business \\ 2018 Vol 2. No I}

Berdasarkan Tabel diatas perhitungan regresi linear berganda dengan menggunakan program SPSS didapat hasil persamaan sebagai berikut: $Y=8,934+0,214 \mathbf{X}_{\mathbf{1}}+0,479 \mathbf{X}_{\mathbf{2}}+0,128 \mathbf{X}_{\mathbf{3}}+\boldsymbol{e}$

\section{Uji R square}

Tabel 9. Hasil uji determinasi

\section{Model Summary}

\begin{tabular}{lr|r|r|r} 
Model & $\mathrm{R}$ & R Square & \multicolumn{1}{c|}{$\begin{array}{c}\text { Adjusted R } \\
\text { Square }\end{array}$} & $\begin{array}{l}\text { Std. Error of the } \\
\text { Estimate }\end{array}$ \\
\hline 1 & $.621^{\mathrm{a}}$ & .386 & .367 & 1.574 \\
\hline
\end{tabular}

Berdasarkan tabel 8menunjukkan besarnya koefisien determinasi $\left(\mathrm{R}^{2}\right)=0,386$. Artinya keputusan pembelian dapat dijelaskan oleh kualitas informasi, persepsi risiko, dan kepercayaan sebesar 38,6\%. Sedangkan sisanya sebesar $61,4 \%(100 \%$ - 38,6\%) dijelaskan oleh sebab-sebab lain yang tidak dimasukkan dalam model penelitian

\section{Uji Hipotesis (Uji F)}

Tabel 10. Hasil uji $F$ ANOVA $^{a}$

\begin{tabular}{ll|r|r|r|r|r} 
Model & Sum of Squares & df & Mean Square & F & \multicolumn{1}{c}{ Sig. } \\
\hline 1 & Regression & 149.283 & 3 & 49.761 & 20.096 & $.000^{\text {b }}$ \\
\cline { 2 - 7 } & Residual & 237.717 & 96 & 2.476 & & \\
\hline Total & 387.000 & 99 & & & \\
\hline
\end{tabular}

Hasil pengujian analisis regresi linear berganda menunjukkan bahwa terdapat nilai signifikansi sebesar $0.000(0.000<0,05)$. Nilai tersebut dapat membuktikan hiopotesis diterima, yang berarti bahwa "Ada Pengaruh Kualitas Informasi, Persepsi Risiko dan Kepercayaan secara bersama-sama terhadap keputusan pembelian secara online"

\section{Uji Hipotesis (Uji t)}

Hasil pengujian analisis regresi linear berganda menunjukkan bahwa terdapat nilai signifikansi sebesar $0.002(0.002<0,05)$. Nilai tersebut dapat membuktikan hipotesis diterima, yang berarti bahwa "Ada Pengaruh Kualitas Informasi secara parsial terhadap keputusan pembelian secara online". 


\section{Journal Competency of Business 2018 Vol 2. No I}

Hasil pengujian analisis regresi linear berganda menunjukkan bahwa terdapat nilai signifikansi sebesar $0.000(0.000<0,05)$. Nilai tersebut dapat membuktikan hipotesis diterima, yang berarti bahwa “Ada Pengaruh Persepsi Resiko secara parsial terhadap keputusan pembelian secara online".

Hasil pengujian analisis regresi linear berganda menunjukkan bahwa terdapat nilai signifikansi sebesar $0.028(0.028<0,05)$. Nilai tersebut dapat membuktikan hipotesis diterima, yang berarti bahwa "Ada Pengaruh Kepercayaan secara parsial terhadap keputusan pembelian secara online".

Tabel 11 Hasil Uji Hipotesis

\begin{tabular}{|c|l|r|}
\hline Hipotesis & \multicolumn{1}{|c|}{ Pernyataan } & Hasil \\
\hline H1 & $\begin{array}{l}\text { Kualitas Informasi, Persepsi Risiko, } \\
\text { dan Kepercayaan berpengaruh positif } \\
\text { terhadap Keputusan Pembelian }\end{array}$ & Diterima \\
\hline H2 & $\begin{array}{l}\text { Kualitas Informasi berpengaruh } \\
\text { positif terhadap Keputusan } \\
\text { Pembelian }\end{array}$ & Diterima \\
\hline H3 & $\begin{array}{l}\text { Persepsi Risiko berpengaruh positif } \\
\text { terhadap Keputusan Pembelian }\end{array}$ & Diterima \\
\hline H4 & $\begin{array}{l}\text { Kepercayaan berpengaruh positif } \\
\text { terhadap Keputusan Pembelian }\end{array}$ & Diterima \\
\hline
\end{tabular}

\section{PEMBAHASAN}

Hasil pengujian analisis regresi linear berganda menunjukkan bahwa terdapat nilai signifikansi sebesar $0.002(0.002<0,05)$. Nilai tersebut dapat membuktikan hipotesis diterima, yang berarti bahwa "Ada Pengaruh Kualitas Informasi secara parsial terhadap keputusan pembelian secara online".

Hasil pengujian analisis regresi linear berganda menunjukkan bahwa terdapat nilai signifikansi sebesar $0.000(0.000<0,05)$. Nilai tersebut dapat membuktikan hipotesis diterima, yang berarti bahwa "Ada Pengaruh Persepsi Resiko secara parsial terhadap keputusan pembelian secara online".

Hasil pengujian analisis regresi linear berganda menunjukkan bahwa terdapat nilai signifikansi sebesar $0.028(0.028<0,05)$. Nilai tersebut dapat membuktikan hipotesis diterima, yang berarti bahwa "Ada Pengaruh Kepercayaan secara parsial terhadap keputusan pembelian secara online".

Hasil pengujian analisis regresi linear berganda menunjukkan bahwa terdapat nilai signifikansi sebesar $0.000(0.000<0,05)$. Nilai tersebut dapat membuktikan hiopotesis diterima, yang berarti bahwa "Ada Pengaruh Kualitas Informasi, Persepsi Risiko dan Kepercayaan secara simultan terhadap keputusan pembelian secara online".

\section{KESIMPULAN DAN SARAN}

\section{Kesimpulan}

1. Kualitas Informasi secara parsial mempengaruhi positif dan signifikan mempengaruhi Keputusan Pembelian.

2. Persepsi Risiko secara parsial mempengaruhi positif dan signifikan mempengaruhi Keputusan Pembelian. 


\section{Journal Competency of Business}

2018 Vol 2. No I

3. Kepercayaan secara parsial mempengaruhi positif dan signifikan mempengaruhi Keputusan Pembelian.

4. Kualitas Informasi, Persepsi Risiko, dan Kepercayaan secara simultan memiliki pengaruh signifikan terhadap Keputusan Pembelian.

\section{Keterbatasan Penelitian}

1. Sampel pada penelitian ini terbatas pada konsumen Tokopedia di Kabupaten Bantul dengan jumlah 100 responden saja.

2. Penelitian ini hanya meneliti pengaruh kualitas informasi, persepsi risiko, dan kepercayaan terhadap keputusan pembelian saja. Sehingga koefisien determinan yang dihasilkan sebesar 38,6\% saja, tergolong rendah dan masih banyak variabel-variabel yang dapat mempengaruhi keputusan pembelian yang tidak dimasukkan ke dalam model penelitian ini. 


\section{Journal Competency of Business \\ 2018 Vol 2. No I}

\section{Saran}

Berdasarkan simpulan dan pembahasan hasil penelitian, saran yang diajukan dalam penelitian ini sebagai berikut:

1. Implikasi praktis

Pengusaha online disarankan untuk meningkatkan kepercayaan konsumen dengan cara memegang teguh kejujuran dalam berbisnis, seperti mengirimkan produk-produk yang telah dibeli kepada konsumen, sehingga keputusan pembelian online di Tokopedia semakin meningkat. Pengusaha online disarankan untuk mengurangi risiko dengan memberikan informasi yang jelas tentang penjualan melalui media sosial kepada konsumen, agar konsumen paham mengenai proses transaksi, memberitahukan kelengkapan produk dan pemilihan kategori yang ditawarkan, sehingga konsumen mempunyai pertimbangan untuk melakukan transaksi melalui Tokopedia dan dapat mendorong keputusan pembelian konsumen

2. Implikasi Teoritis

a. Bagi peneliti selanjutnya, Akan lebih baik jika sampel yang diambil meliputi seluruh konsumen Tokopedia yang sudah pernah melakukan pembelian tidak hanya di Kabupaten Bantul, sehingga hasil penelitian dapat digeneralisasikan dalam lingkup yang lebih luas.

b. Dengan koefisien determinan yang sebesar $38,6 \%$ dan tergolong rendah, artinya sebanyak $61,4 \%$ keputusan pembelian dipengaruhi oleh variabel lain yang tidak dimasukkan dalam model penelitian ini. Bagi peneliti selanjutnya sebaiknya memasukkan variabel lain yang dapat mempengaruhi keputusan pembelian seperti kemudahan, tampilan produk, kualitas layanan, dan manfaat produk sehingga dapat dilihat apa yang paling berpengaruh dalam pengambilan keputusan berbelanja online. 


\section{Journal Competency of Business 2018 Vol 2. No I}

\section{DAFTAR PUSTAKA}

APJII.2019.Penetrasi \& Perilaku Pengguna Internet Indonesia. https:apjii//.or.id/. (diakses 04Oktober 2019)

Ghozali, Imam. 2011. Aplikasi Analisis Multivariate Dengan Program SPSS. Semarang: Universitas Diponegoro.

iPrice.2019.Top 50 Ecommerce Sites and Apps in Indonesia 2019. https:iprice.co.id/. (diakses 04 Oktober 2019)

Istiqomah, Hidayat, Z., \& Jariah, A. (2019). Analisis Pengaruh Kepercayaan , Iklan dan Persepsi Resiko Terhadap Keputusan Pembelian di situs Shopee di Kota Lumajang, 2(July), 557-563.

Juniwati. 2014. Influence of Perceived Usefulness, Ease of Use, Risk on Attitude and Intention to Shop Online. European Journal of Business and Management. www.iiste.org Vol.6, No.27.

Kotler, P., \& G. Armstrong. 2016. Principle of Marketing Edisi 15. Ebook: Pearson.

Kotler, Philip dan Kevin Lane, Keller. 2009. Manajemen Pemasaran. Jilid 1 dan 2. Edisi 13. Jakarta: Erlangga.

Kotler, Phillip \& Keller, Kevin Lane. 2012. Marketing Management (14thed). United State : Pearson.

Lee, Y.,2014.Impacts of decision-making bases on eWOMretrustandriskreducingstrategies.Comput.Hum.Behav.40,101-110.

Li, H.Jiang,J.,Wu,M.2014.The effects of trust assurances on consumers'initial online trust:a twostage decision-making process perspective.Int.J.Inf. Manag. 34(3),395-405.

Loo Sin Chun. 2011. The Impact of The Special Dividend Announcement on TheStock Return: The Case of Malaysia. Journal of International Business Research, Volume 10, Special Issue Number 1.

Machfoedz, M. 2013. Pengantar Pemasaran Modern. Akademi Manajemen Pemasaran YPKPN, Yogyakarta.

Rizki, K., Astuti, E. S., \& Susilo, H. (2015). Pengaruh Kemudahan Dan Kualitas Informasi Terhadap Minat Dan Keputusan Pembelian Secara Online. Administrasi Bisnis, 28(1), 56-63.

Sukma, Abdurrahman Adi., 2012, Analisis Faktor-Faktor Yang Mempengaruhi Keputusan Pembelian Social Networking Websites, Jurnal Ekonomi Manajemen, Fakultas Ekonomi Universitas Gunadarma.

Sutabri, Tata. 2012. Konsep Sistem Informasi. Yogyakarta: Andi.

Sugiyono, 2011. Metode Penelitian Kuantitaif Kualitatif dan R \& B, Bandung: Alfabeta.

Sugiyono. 2012. Metode Penelitian Kuantitatif dan R\&D. Bandung: Alfabeta.

Sugiyono. 2013, Metode Penelitian Administrasi. Alfabeta, Bandung

Xian, Gou Li. 2011. Corporate Product and User Image Dimensions and Purchase Intention. Journal of Computers, (6)9: 18751879 